\title{
The role of exercise in reducing the side effects of antipsicotics used in the treatment of bipolar disorders
}

\author{
Hatice TOY ${ }^{1}$, Erkut TUTKUN ${ }^{1}$, Itır TARI CÖMERT ${ }^{2}$ \\ ${ }^{1}$ Bursa Uludag University, Faculty of Sport Science, Turkey \\ 2 Fatih Sultan Mehmet Vakuf University, Faculty Of Education, İstanbul, Turkey \\ Address Correspondence to E, Tutkun, e-mail: erkuttutkun@uludag.edu.tr
}

\begin{abstract}
The study is a systematic evaluation of quantitative studies showing the relationship between drug use and physical activity in investigating the side effects of antipsychotics used in patients who have bipolar disorder.

Bipolar disorder is usually treated with medicine and the side effects of the drugs which are used to increase the body mass index of patients and this causes obesity. This study mainly aims to examine the role of exercise in reducing the side effects of antipsychotics which are used by individuals who have bipolar disorder with using the high-level evidence which was acquired from published systematic reviews and meta-analyzes.

Most antipsychotics cause weight gain; olanzapine and clozapine are seen as the antipsychotics which have highest risk. In the first period after taking antipsychotics, the weight is increasing rapidly, and patients continue to gain weight in the long term. One of the best strategies to prevent this situation is to adapt antipsychotics according to individual needs and to check over weight and other metabolic parameters closely.

The researches which were done and current information in the last 10 years were included in the study. Recent studies have shown that in the patients who have bipolar disorder, physical activity programs can play a significant role in supporting of mental and physical health. We hope that adding exercise to treatment plans for individuals with bipolar disorder may provide side benefits and be guidance for clinical practice, policy and future research.
\end{abstract}

Keywords: Bipolar disorder, Antipsychotics, Obesity, Exercise

\section{INTRODUCTION}

Bipolar disorder is a mental health status that can cause low depressive and high manic disorder. While most people experience a slight mood wave, fluctuations in individuals with bipolar disorder may be excessive and unpredictable. Bipolar disorder which is formerly named as a "manic depression" is a mental disorder characterized by serious and significant mood changes.

A person who has this condition experiences "rises or overflow" (mania) and "self-abasement or collapse" (depression). Both manic and depressive episodes are only shorter than a few hours to a few days or longer, and can last for several weeks and months. Although the periods of mania and depression vary from person to person, most people can experience very short periods of these intense moods and do not even realize that they have this disorder (5). As reported by another definition, bipolar disorder is a "fatal disorder" with high comorbidity rates and early recognition of bipolar disorder is reported to be beneficial in reducing disease-related comorbidities and mortality in an effective treatment process (29).

The diagnosis of bipolar disorder is also associated with an increased risk of cardiovascular disease which leads to premature death $(38,17,11)$. On that occasion, obesity and sedentary lifestyle diabetes are risk factors for metabolic syndrome and cardiovascular diseases and often affect individuals who have bipolar disorder $(3,7,25)$. Therefore, individuals who have bipolar disorder are confronted with the need to focus their treatment not only on their mental health, but also on their physical health.

At this point, exercise is a magnificent way to meet this need and also shows that it is an effective treatment in reducing depression and anxiety by contributing to the improvement of conditions that negatively affect physical health (obesity, 
cardiorespiratory compliance, hypertansion, cholesterol) (33, Rethorst \& Trivedi, 2013). When some data are taken into consideration to reduce depression and anxiety, exercise may also be useful in the treatment of bipolar disorder. These data have provided to the adoption of mild to moderate exercise as the first treatment method to reduce depression (8). Specifically, exercise shows that it is partly associated with increased brain-derived neurotrophic factor (43).

According to the European Psychiatric Association, there are four main categories of bipolar disorder. These are bipolar I disorder, bipolar II disorder, cyclothymic disorder and bipolar disorder due to improper use of substance (Stubbs et al., 2018). All types of bipolar disorder usually respond to treatment, for this reason, it requires many years for drug use and treatments such as psychotherapy.

\section{Symptoms of bipolar disorder}

For the diagnosis of bipolar disorder, a person must have had at least one manic and one depressive period during his or her life.

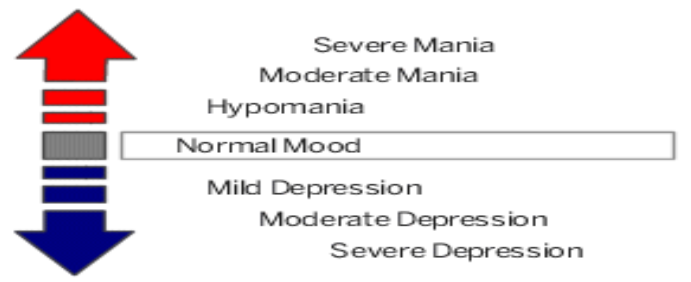

Figure I. Symptoms of bipolar disorder (Bressert, 2019)

Manic episode (bipolar I disorder) is characterized by excessive speech, extreme uneasiness, hyperactivity, low sleep need and / or intense thoughts. In a manic period, individuals believe that they are able to do everything, do plan and do all these things, and they feel as if nothing can stop them. For the diagnosis of bipolar I, this period lasts at least one week and shows an alteration from a person's usual behavior.

Hypomanic episode (bipolar II disorder) is characterized by the same symptoms as a manic period, but it is a condition where symptoms proceed for at least four days.

In the depressive episode, excessive sadness, lack of energy, or lack of interest in certain things, is often characterized by feelings of lack of pleasure in activities, helplessness and hopelessness. Anyone with this condition may experience normal mood up to three years between mania and depression. When not treated, the severity of the periods change and the severity of the symptoms increase.

The prevalence of bipolar disorder (BD) is $0.6 \%$ for lifetime BD-I and $0.4 \%$ for BD-II among cultures and ethnic groups. BD ranks sixth among mental disorders and 20th among all diseases in the world. According to the general population, life expectancy of BD individuals is less than 10 years (49).

The obesity is common in patients who have bipolar disorder and it is associated with increased medical morbidity and poor psychiatric outcomes. Genetic factors, neurotransmitter abnormalities, atypical depression, eating behaviors, pharmacotherapy, age, gender, socioeconomic status and physical inactivity are effective variables that can interact to prevent onset and prevention of obesity in bipolar disorder. Although the causes of obesity in bipolar disorder vary among patients, they directly or indirectly include pharmacological, biological, psychological, and socio-demographic variables, and the sedentary lifestyle, which leads to obesity in this population, affects the disturbances in eating behavior and the drugs used (52). Therefore, there is a need for behavioral studies that increase physical activity and reduce over-eating in patients who have bipolar disorder.

\section{Antipsychotic Use in Bipolar Disorder;}

Antipsychotic drugs in bipolar disorder are used in addition to treatment to control psychotic symptoms such as hallucinations, delusions or mania. These symptoms may occur during acute mania or severe depression. Antipsychotics help in the prevention of future mania or depression attacks while treating bipolar depression. In people with bipolar disorder, antipsychotics are also often used in combination with mood stabilizers to prevent and balance drug use, insomnia, anxiety and/or agitation and may reduce manic symptoms until mood stabilizers are fully effective (22). It is observed that some antipsychotics help to stabilize their moods on their own. Consequently, it is used alone as a longterm treatment in individuals who do not tolerate or respond to lithium and anticonvulsants (20).

Antipsychotic drugs help to regulate the functioning of cognitive functions by controlling thought, mood and perception. Although it is not known exactly how these drugs work, it is usually seen that they quickly heal manic attacks. Aripirazole (abilify), asenapine (sapphire), kariprazin (vraylar), clozapine (clozaril), lurasidone 
(latuda), olanzapine (zyprexa), quetiapine (seroquel), risperidone (risperdal), ziprasidone (geodon) are the antipsychotics which are used to treat bipolar disorder. Some of these drugs cause significant weight gain, high cholesterol levels and increase the risk of diabetes. As metabolic side effects of these drugs cause serious health problems in bipolar patients, exercise and healthy nourishment are important in these individuals.

The fastest weight gain takes place in the first 6 months after starting an antipsychotic treatment and then continues slowly. Table I shows the risk of weight gain with different antipsychotics.

Table 1. Weight gain with different Antipsychotics (Cooper et al., 2016).

\begin{tabular}{llll}
\hline Antipsychotics & & Risk Of Weight Gain \\
\hline$\bullet$ & Olanzapine & $\Longrightarrow$ & High \\
\hline$\bullet$ & Clozapine & & High \\
\hline$\bullet$ & Chlorpromazine & & High / Moderate \\
\hline$\bullet$ & Quetiapine & & Moderate \\
\hline$\bullet$ & Risperidone & $\longrightarrow$ & Moderate \\
\hline$\bullet$ & Paliperidone & & Moderate \\
\hline$\bullet$ & Asenapine & & Low \\
\hline$\bullet$ & Amisulpride & & Low \\
\hline$\bullet$ & Aripiprazole & $\Longleftrightarrow$ & Low \\
\hline$\bullet$ & Lurasidone & Low \\
\hline$\bullet$ & Ziprasidone & & Low \\
\hline$\bullet$ & Haloperidol & & Low \\
\hline & & & \\
\hline
\end{tabular}

Weight gain due to antipsychotics is a important management problem for clinicians. Weight gain and obesity have been shown that it leads to increased cardiovascular and cerebrovascular morbidity and mortality and reduced quality of life (9).

In addition to weight gain, antipsychotics are also known that they impair glucose metabolism, increase cholesterol and triglyceride levels, cause arterial hypertension and lead to metabolic syndrome (13). It has been reported that metabolic syndrome will increase the risk of diabetes mellitus by five times and the risk of cardiovascular disease Turk ل Sport Exe 2019; 21(1):S6-109 (1) 2019 Faculty of Sport Sciences, Selcuk University twice in the next 5-10 years (9). The increased metabolic syndrome and obesity prevalence lead to a decrease in lifespan and an increase in mortality rates in psychiatric patients (34).

Allison and colleagues (2) evaluated that weight gain associated with both first- and secondgeneration antipsychotics (FGAs and SGAs) at standard doses for 10 weeks. While most of the antipsychotics caused weight gain, patients who took placebo lost weight. An average loss of $0.39 \mathrm{~kg}$ of weight loss was reported for Molindone, whereas clozapine, olanzapine, thioridazine, sertindole, chlorpromazine and risperidone were all reported that they cause in a significant weight gain ranging from 4.45 to $2.10 \mathrm{~kg}$.

Leucht and colleagues (27), 6-week multidisciplinary treatment data using the metaanalysis, indicated that haloperidol, lurasidone and all other antipsychotics except ziprasidone cause weight gain, and olanzapine and zotepine induce more weight gain than other antipsychotics.

In another study, it was observed that while olanzapine and clozapine caused the highest weight gain, quetiapine, risperidone and sertindole caused a small amount of weight gain and aripiprazole and amilsulpride users had low-moderate weight whereas ziprasidone caused the lowest weight gain (40). De Hert and colleagues (14) reported that asenapine, iloperidone, paliperidone and lurasidone were effective in weight gain from new generation antipsychotics.

Bak and colleagues (4) found that most antipsychotics except aripiprazole, amilsulpride and ziprasidone, including FGAs, provided significant weight gain. Significant weight gain was observed in the first 6 weeks in the groups which took antipsychotics. Interestingly, a significant proportion of patients showed a clinically significant weight loss in amilsulpride, aripiprazole, asenapine, olanzapine, paliperidone and ziprasidone in more than $7 \%$ of the basal weight.

\section{The mechanisms underlying weight gain and other metabolic abnormalities caused by antipsychotics;}

Many mechanisms have been proposed to explain the weight gain caused by antipsychotics. The amount of weight gain depends on the antipsychotic type and the individual characteristics of the patients. Most research focuses on clozapine 
and olanzapine, the two drugs which are found to cause the highest weight gain. The possibility of high weight gain with these drugs has been associated with the effects on serotonin 5-HT2A and 5-HT2C, dopamine D2 and D3, histamine H1 and muscarinic M3 receptor (19). Differential effects on body weight are explained by the different affinity of drugs at these receptors (23).

Antipsychotics affect neuropeptides which are associated with appetite control and energy metabolism. Leptin and adiponectin are adipokinine which are produced in white adipose tissue in AIWG. Adiponectin levels which were decreased and increasing leptin levels with short and long term olanzapine treatment were denoted (1). An increase in food intake and accumulation of adipose tissue is affected by the use of antipsychotics by the hormone Ghrelin, which acts on the curved nucleus of the hypothalamus. Changes in leptin, adiponectin and ghrelin levels were determined to be due to direct effects of drugs on weight gain (28). On the other hand, the effects of antipsychotics on lipid and glucose metabolism which are associated with their effects caused on weight gain and adipocyte tissue, resulting in insulin resistance and consequently increasing the release of very low density lipoproteins from triglycerides and adiposities. There is also evidence that antipsychotics increase the expression of sterol regulatory element binding protein (SREBP) and very low density lipoprotein (VLDL) genes (21).

Genetic polymorphisms can explain the physical change in AIWG. In the meta-analysis of Zhang et al. (54), 13 single nucleotide polymorphisms from the nine genes that were significantly associated with AIWG were identified. The single nucleotide polymorphisms which are associated with ADRA2A, DRD2, 5-HTR2C and MC4R genes have shown the greatest effect by showing that candidate genes are also associated with receptors in which weight loss is demonstrated by the therapeutic effects of antipsychotics.

The results of the study which was published in 2014 and in the post-2014 study are presented in Table II.

Table 2. The Relationship between Weight Increase and Interaction Due to Antipsychotics which are used by Patients who have Bipolar Disorder

\begin{tabular}{|c|c|c|c|c|}
\hline Researchers & Year & Population & Medication which is used & Results \\
\hline Rubio-Terrres et al. & 2014 & $\begin{array}{l}\text { Bipolar } \\
\text { Disorder }\end{array}$ & $\begin{array}{l}\text { Aripiprazole (ARI) and } \\
\text { Olanzapine (OLA) }\end{array}$ & $\begin{array}{l}\text { Patients who were treated with } \\
\text { aripiprazole had lower side effects than } \\
\text { olanzapine. }\end{array}$ \\
\hline Creta et al. & 2015 & $\begin{array}{l}\text { Bipolar } \\
\text { Disorder } \\
(\mathrm{n}=486)\end{array}$ & Olanzapine and Clozapine & $\begin{array}{l}\text { HTR2C, LEP, FTO and TBC1D1 } \\
\text { represented genes related to weight gain } \\
\text { during treatment with a SGA. Obesity- } \\
\text { related genome-wide (FTO rs9930506) } \\
\text { has been associated with psychotropic } \\
\text { weight gain. }\end{array}$ \\
\hline Rado \& Cavanaugh & 2016 & $\begin{array}{l}\text { Schizophrenia } \\
\text { Schizoaffective } \\
\text { Disorder } \\
\text { Bipolar } \\
\text { Disorder, (t:24 } \\
\text { weeks- } \\
\text { n:25) }\end{array}$ & $\begin{array}{l}\text { Olanzapine+ Metformin } \\
\text { Olanzapine+ Placebo }\end{array}$ & $\begin{array}{l}\text { The average change in body weight for } \\
\text { the olanzapine + metformin }(\mathrm{O} / \mathrm{M}) \text { group } \\
\text { was found to be } 5.5 \mathrm{~kg} \text { and } 12.8 \mathrm{~kg} \text { for } \\
\text { olanzapine + placebo }(\mathrm{O} / \mathrm{P}) \text { group. } \\
\text { Patients in the } \mathrm{O} / \mathrm{M} \text { group had a } \% 3 \\
\text { increase a weight compared with the } \mathrm{O} / \mathrm{P} \\
\text { group who gained } \% 7 \text { of their body } \\
\text { weight (p<0.037). Body mass index } \\
\text { change in O/M group was } 0.85 \text { versus } \\
2.02 \text { in } \mathrm{O} / \mathrm{P} \text { group (p<0.045). In O/P } \\
\text { group, insulin resistance and waist } \\
\text { circumference were increased compared } \\
\text { with O/M group. Metformin is an } \\
\text { effective way to prevent Olanzapine- } \\
\text { derived weight gain. }\end{array}$ \\
\hline Talaeı et al. & 2016 & $\begin{array}{l}\text { Schizophrenia } \\
\text { Bipolar } \\
\text { Disorder } \\
\text { (n:68 }\end{array}$ & $\begin{array}{l}\text { Olanzapine } \\
\text { Placebo } \\
\text { Topiramate }\end{array}$ & $\begin{array}{l}\text { All doses of } 50,100 \text { and } 200 \mathrm{mg} \text { (placebo } \\
\text { and topiramate) have been shown that } \\
\text { they are effective in the prevention of } \\
\text { Olanzapine-derived obesity in }\end{array}$ \\
\hline
\end{tabular}




\begin{tabular}{|c|c|c|c|c|}
\hline & & t:12 weeks) & & $\begin{array}{l}\text { schizophrenia and/or patients who have } \\
\text { bipolar disorder. }\end{array}$ \\
\hline Detke et al. & 2016 & $\begin{array}{l}\text { Schizophrenia } \\
\text { Bipolar } \\
\text { Disorder } \\
\mathrm{n}=102 \\
\mathrm{t}=52 \text { weeks }\end{array}$ & Olanzapine & $\begin{array}{l}\text { In both groups, the increase in BMI due } \\
\text { to olanzapine was high. Intensive } \\
\text { behavioral controlled studies are needed } \\
\text { to assess the tolerability of oral } \\
\text { olanzapine and to reduce the risk of } \\
\text { weight gain for adolescents who have } \\
\text { schizophrenia and bipolar mania. }\end{array}$ \\
\hline Fang et al. & 2017 & $\begin{array}{l}\text { Bipolar } \\
\text { Disorder }\end{array}$ & $\begin{array}{lr}\text { SGAs } & \text { (olanzapine, } \\
\text { asenapine, } & \text { quetiapine, } \\
\text { risperidone, aripiprazole, } \\
\text { paliperidone, ziprasidone) }\end{array}$ & $\begin{array}{l}\text { The weight gain and metabolic side } \\
\text { effects of second generation } \\
\text { antipsychotics in bipolar disorder were } \\
\text { investigated. Antipsychotics which were } \\
\text { used in short and long-term studies were } \\
\text { found that they caused weight gain } \\
\text { compared to placebo. }\end{array}$ \\
\hline Meyer et al. & 2017 & $\begin{array}{l}\text { Bipolar } \\
\text { Disorder } \\
\text { Schizophrenia }\end{array}$ & Lurasidone & $\begin{array}{l}\text { Lurasidone was associated with weight } \\
\text { loss in } 1 \text { year after the patients who have } \\
\text { schizophrenia and bipolar disorder. } \\
\text { Analyzes showed that weight loss was } \\
\text { more apparent in patients who are using } \\
\text { second-generation antipsychotics which } \\
\text { are associated with the risk of more } \\
\text { weight gain before lurasidone treatment. }\end{array}$ \\
\hline Ostacher et al. & 2018 & $\begin{array}{l}\text { Bipolar } \\
\text { Disorder }\end{array}$ & $\begin{array}{l}\text { Lurasidone } \\
\text { Quetiapine } \\
\text { Aripiprazole } \\
\text { Olanzapine } \\
\text { Ziprasidone }\end{array}$ & $\begin{array}{l}\text { They aimed to evaluate the efficacy and } \\
\text { tolerability of lurasidone against other } \\
\text { atypical antipsychotic mono therapy } \\
\text { agent in bipolar patients. Tolerability } \\
\text { results included weight gain, state of } \\
\text { sleep, extrapyramidal symptoms (EPS). } \\
\text { Results: lurasidone was found that it was } \\
\text { more effective than aripiprazole and } \\
\text { ziprasidone and had less weight gain } \\
\text { than quetiapine and olanzapine and was } \\
\text { associated with less sleepiness than } \\
\text { quetiapine and ferazidone. }\end{array}$ \\
\hline Vieta \& Montes & 2018 & $\begin{array}{l}\text { Bipolar } \\
\text { Disorder }\end{array}$ & Asenapine & $\begin{array}{l}\text { Asenapine has been shown that it is } \\
\text { effective reducing clinically significant } \\
\text { depressive symptoms in patients who } \\
\text { have bipolar I disorder. Drowsiness, } \\
\text { dizziness, extrapyramidal symptoms, } \\
\text { increased body weight and oral } \\
\text { hypoesthesia are the most common side } \\
\text { effects which are associated with } \\
\text { asenapine. In addition to this, the } \\
\text { frequency of these events, especially } \\
\text { weight gain, was generally lower than } \\
\text { olanzapine. Besides, it has been shown } \\
\text { that asenapine improves health-related } \\
\text { quality of life. }\end{array}$ \\
\hline Butler et al. & 2018 & $\begin{array}{l}\text { Bipolar } \\
\text { Disorder }\end{array}$ & $\begin{array}{l}\text { Asenapine, kariprazin, } \\
\text { quetiapine and olanzapine } \\
\text { Risperidone, ziprasidone } \\
\text { divalproex/valproat }\end{array}$ & $\begin{array}{l}\text { The results showed that risperidone and } \\
\text { ziprasidone had a generally beneficial } \\
\text { effect on acute mania symptoms } \\
\text { compared to placebo. Participants who } \\
\text { are using atypical antipsychotics, except } \\
\text { quetiapine, reported more } \\
\text { extrapyramidal symptoms than placebo, } \\
\text { clinically significant weight gain was } \\
\text { observed in olanzapine users. There were } \\
\text { no differences between olanzapine and } \\
\text { divaproex / valproate for acute mania. }\end{array}$ \\
\hline
\end{tabular}

Butler and colleagues (6) evaluated the effect of drug and non-drug treatments in the treatment of acute symptoms related to bipolar disorder and prevention of recurrence. His studies included prospective cohorts and comparative randomized controlled trials which registered adults who have 
bipolar disorder (BD), 3 weeks for acute mania and every week for 3 to 6 months for depression. Asenapine, kariprazine, quetiapine and olanzapine improved acute mania symptoms compared to placebo. Risperidone and ziprasidone have generally shown a beneficial effect on acute mania symptoms compared to placebo. Participants who are using atypical antipsychotics, except quetiapine, reported more extrapyramidal symptoms than placebo, and clinically significant weight gain was observed in olanzapine users. There were no differences between olanzapine and divalproex / valproate for acute mania.

Meyer and colleagues (32) in their studies, serious psychiatric disorders such as schizophrenia and bipolar disorder are associated with increased risk of obesity compared to the general population. The relationship between lurasidone and low weight gain risk has been established in short and long-term clinical trial settings, while the information about the association of lurasidone with weight gain in normal clinical care remains limited. The body weight data of the participants based on drug use were analyzed in depth to estimate the effect of lurasidone on the body weight of the patient. The body weight data $(\mathrm{kg})$ of the patients with schizophrenia or bipolar disorder were followed up for 12 months after the initiation of lurasidone and were associated with weight loss at the end of 1 year. Second-generation antipsychotics with intermediate-high risk (clozapine, olanzapine, quetiapine or risperidone) were analyzed based on first-generation antipsychotic use because of low weight gain (aripiprazole, ziprasidone). Analyzes have shown that weight loss is more significant in patients who are using second-generation antipsychotics associated with the risk of more weight gain before lurasidone treatment. These findings are consistent with the results of previous prospective studies and suggest that lurasidone is associated with a lower risk of weight gain in patients who have schizophrenia or bipolar disorder.

According to In Vieta and Montes (51) studies, asenapine treatment in adult and patients who have pediatric has been found that it is effective in the short and long-term treatment of mania associated with bipolar I disorder. Asenapine is a second generation antipsychotic which is approved in the US (brand Saphris $®$ ) for manic treatment in Europe (brand Sycrest ${ }^{\circledR}$ ) for the treatment of moderate to severe manic attacks associated with bipolar I disorder in adults.

Asenapine is an antagonistic activity at the D2 receptor, which is probably responsible for its antimanic features.

In addition, asenapine has been found that it is effective in reducing clinically significant depressive symptoms in patients who have bipolar I disorder. Drowsiness, dizziness, extrapyramidal symptoms, increased body weight and oral hypoesthesia are the most common side effects which are associated with asenapine. In addition to this, the frequency of these events, especially weight gain, was generally lower than olanzapine.

Ostacher and colleagues (35) aim to evaluate the efficacy and tolerability of lurasidone against other atypical antipsychotic mono therapy agents in patients who have bipolar disorder in their studies. They incorporated into 14 randomized clinical trials ( $\mathrm{n}=6221$ patients), lurasidone, quetiapine (extended release and immediate release), aripiprazole, olanzapine, and ziprasidone in their studies. While results included weight gain, drowsiness, extrapyramidal symptoms (EPS); lurasidone is more effective than aripiprazole and ziprasidone and also it was found that it is associated with less weight gain and less drowsiness than quetiapine and olanzapine.

\section{Bipolar Disorder: A Deadly Disease with Dangerous Comorbidities;}

Physical activity has an inverse relationship with sleep duration in the individuals who have bipolar disease. While more activity usually continues with less sleep at night, more sleep tends to lead to less activity the next day. Merikangas and colleagues (31) determined that changes in internal psychological conditions among the participants with bipolar I disorder were strongly influenced by sleep and physical activities. Nonetheless, researchers have indicated that many studies on mood, sleep, and activity tend to focus on a particular system rather than taking into account the collective impact of the systems. The findings of the study included studies to balance depressive periods in patients who have bipolar disorder. They stated that studies which are focusing on motor activity and energy have more efficiency than existing approaches, and that both active and passive monitoring of multiple regulatory systems are significant in designing therapeutic objects. 
The study included 12 studies which are examining the physical activity levels of individuals who have bipolar disorder.

Table 3. The relationship between physical activity level and outcome of individuals with bipolar disorder

$\begin{array}{llll}\text { Researchers } & \text { Year Pattern } & \begin{array}{l}\text { Population/ } \\ \text { Examination }\end{array} & \text { Context }\end{array}$

\begin{tabular}{|c|c|c|c|c|}
\hline Van Citters et al. & 2010 & $\begin{array}{l}\text { Randomized } \\
\text { Controlled } \\
\text { Study }\end{array}$ & $\begin{array}{l}\mathrm{BMW}, \mathrm{n}=30 \\
\mathrm{HC}, \mathrm{n}=19 \\
\mathrm{SG}, \mathrm{n}=18 \\
(\mathrm{n}=76)\end{array}$ & $\begin{array}{ll}\text { Moderate walking exercise } & \text { It was found that the participants } \\
\text { and the acquisition of } & \text { had a significant increase in exercise } \\
\text { healthy nutritional habits } & \text { and mental and physical health, and } \\
\text { accompanied by a health } & \begin{array}{l}\text { a significant decrease in waist } \\
\text { consultant }\end{array}\end{array}$ \\
\hline
\end{tabular}

Study duration $=9$ months

\begin{tabular}{|c|c|c|c|c|c|}
\hline \multirow{8}{*}{ Sylvia et al. } & \multirow{8}{*}{2011} & \multirow{8}{*}{ Prospective } & $\mathrm{BD}$ & \multirow{8}{*}{$\begin{array}{l}\text { It consists of } 3 \\
\text { Treatment modules } \\
\text { (Nutrition, exercise and } \\
\text { healthy life) with } 12 \\
\text { sessions of } 12 \text { minutes } \\
\text { for } 14 \text { weeks. }\end{array}$} & \multirow{8}{*}{$\begin{array}{l}\text { Both groups exercised more } \\
\text { than } 100 \text { minutes per week. } \\
\text { While there was no } \\
\text { Momentous difference in } \\
\text { group 1, the depressive and } \\
\text { manic symptoms and body } \\
\text { weight decreased and quality } \\
\text { of life advanced in group } 2 \text {. }\end{array}$} \\
\hline & & & Group I, n=4 & & \\
\hline & & & Group II, n=6 & & \\
\hline & & & & & \\
\hline & & & & & \\
\hline & & & & & \\
\hline & & & & & \\
\hline & & & & & \\
\hline
\end{tabular}

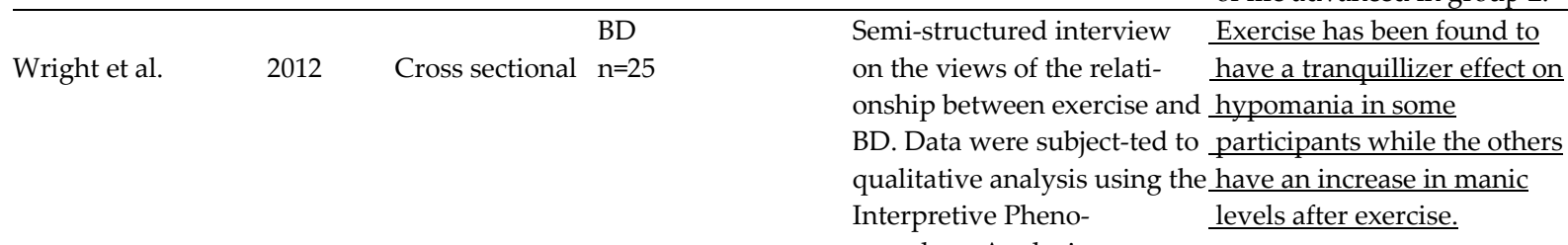

menology Analysis approach.

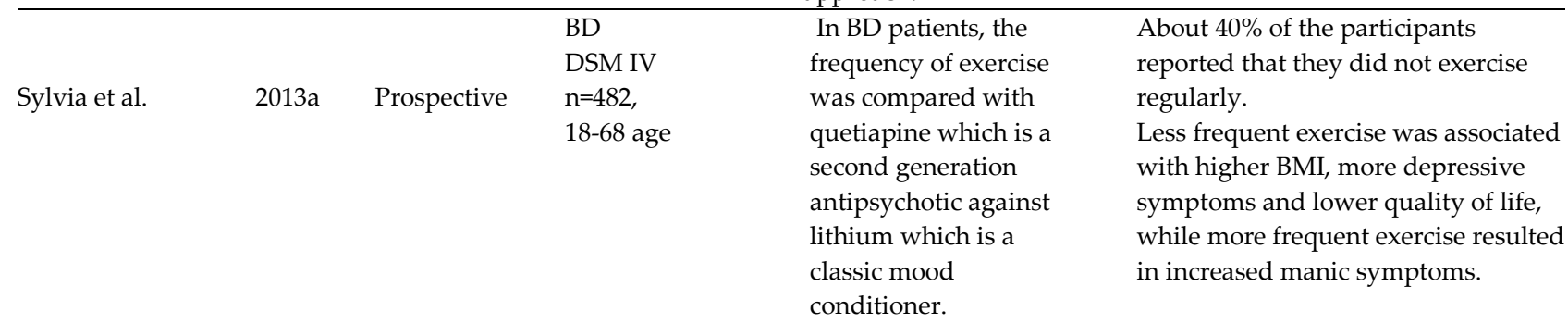

\begin{tabular}{|c|c|c|c|c|c|}
\hline Sylvia et al. & $2013 b$ & Prospective & $\begin{array}{l}\mathrm{BD} \\
\mathrm{n}=5 \\
\text { age between } \\
23 \text { to } 64\end{array}$ & $\begin{array}{l}\text { Participants } \\
\text { participated in a 20- } \\
\text { week Cognitive } \\
\text { Behavioral Therapy } \\
\text { which consisted of a } \\
\text { therapy of Nutrition, } \\
\text { Exercise and Healthy } \\
\text { Living module. }\end{array}$ & $\begin{array}{l}\text { The weight, cholesterol and } \\
\text { triglycerides of the participants } \\
\text { decreased as well as daily calorie and } \\
\text { sugar intake during the study period. } \\
\text { Weekly exercise duration increased } \\
\text { threefold and depressive symptoms } \\
\text { decreased. }\end{array}$ \\
\hline Daumit et al. & 2013 & $\begin{array}{l}\text { Retrospective } \\
\text { Study }\end{array}$ & $\begin{array}{l}\text { BD } \\
\mathrm{n}=64 \\
\text { Schizophrenia } \\
\text { Schizo- affective, } \\
\text { MDD, } \\
\mathrm{n}=291\end{array}$ & $\begin{array}{l}\text { The study includes } \\
\text { group exercise sessions } \\
\text { and individual weight } \\
\text { management sessions. } \\
\text { Operating time }=18 \\
\text { months }\end{array}$ & $\begin{array}{l}\text { It was stated that the experimental } \\
\text { group lost more weight than the } \\
\text { control group and } 37.8 \% \text { of the } \\
\text { participants in the experimental } \\
\text { group lost at least } 5 \% \text { of the initial } \\
\text { body weight compared to } 22.7 \% \text { of } \\
\text { the participants in the control group. }\end{array}$ \\
\hline Vancampfort et al. & 2013 & $\begin{array}{l}\text { Systematic } \\
\text { review } \\
\text { Meta-analysis }\end{array}$ & $\begin{array}{l}\text { Related publications } \\
\mathrm{n}=11 \text { article }\end{array}$ & $\begin{array}{l}\text { A study of physical } \\
\text { activity in patients who } \\
\text { have bipolar disorder }\end{array}$ & $\begin{array}{l}\text { The increase in body mass indexes of } \\
\text { individuals who have bipolar } \\
\text { disorder originated the sedentary } \\
\text { lifestyle, some demographic factors } \\
\text { and the inadequacy of their } \\
\text { participation in physical activities. }\end{array}$ \\
\hline
\end{tabular}




\begin{tabular}{|c|c|c|c|c|c|}
\hline Jenney et al. & 2014 & Prospective & $\begin{array}{l}\mathrm{BD} \\
\mathrm{N}=60\end{array}$ & $\begin{array}{l}\text { It includes the weekly 150- } \\
\text { minute walking exercise } \\
\text { recommended by the EPA. } \\
\text { Adult patients treated for } \\
\text { BD (>18 years) were } \\
\text { measured for seven days. }\end{array}$ & $\begin{array}{l}\text { It was determined that the } \\
\text { participants could not complete the } \\
\text { weekly 150-minutes medium/severe } \\
\text { exercise recommended by EPA. In } \\
\text { bipolar disorder, excessive weight, } \\
\text { smoking habits, sedentary lifestyle, } \\
\text { night eating syndrome and side } \\
\text { effects of the drugs used had a } \\
\text { negative effect on physical activity. }\end{array}$ \\
\hline Melo et al. & 2016 & $\begin{array}{l}\text { Systematic } \\
\text { review }\end{array}$ & Related publications & $\begin{array}{l}31 \text { randomized control-ed } \\
\text { studies which is examining } \\
15,587 \text { patients who have } \\
\text { bipolar disorder }\end{array}$ & $\begin{array}{l}\text { The depressive symptoms of bipolar } \\
\text { patients who are attending physical } \\
\text { activities decreased and their quality } \\
\text { of life and functionality increased. }\end{array}$ \\
\hline Merikangas et al. & 2018 & Case Study & $\begin{array}{l}\text { BD I }=25 \\
\text { BD II }=29 \\
\text { MDD }=91 \\
\text { Control } \\
\text { (healthy) } \\
n=242\end{array}$ & $\begin{array}{l}\text { Motor activity and sleep } \\
\text { time data were obtained to } \\
\text { the very minute with a non- } \\
7 \text { combined wrist insertion } \\
\text { device for } 2 \text { weeks. } \\
\text { Mood and energy levels } \\
\text { (using a personal digital } \\
\text { clock) were evaluated with } \\
\text { analog scoring } 4 \text { times a day } \\
\text { for } 2 \text { weeks. }\end{array}$ & $\begin{array}{l}\text { It was observed that motor } \\
\text { activity in bipolar disorder had a } \\
\text { greater reactivity among all } \\
\text { results, including sleep, mood, } \\
\text { and energy. }\end{array}$ \\
\hline Stubbs et al. & 2018 & Meta analysis & $\begin{array}{l}\text { BD I,II } \\
\text { schizophrenia } \\
\text { MDD }\end{array}$ & $\begin{array}{l}\text { EPA guidance on physical } \\
\text { activity for the treatment of } \\
\text { severe mental disorders: The } \\
\text { European Psychiatric } \\
\text { Association (EPA) Guide } \\
\text { supported by the } \\
\text { International Organi-zation } \\
\text { for Mental Health Physical } \\
\text { Therapists (IOPTMH) }\end{array}$ & $\begin{array}{l}\text { Researchers reported that exercise } \\
\text { effectively decreased symptoms of } \\
\text { mental disorder, improved } \\
\text { cognitive functions, and enhanced } \\
\text { cardiovascular health among } \\
\text { schizophrenic patients. Results of } \\
\text { the study shows that aerobic } \\
\text { exercise which was performed at } \\
\text { moderate intensity for at least } 150 \\
\text { minutes twice a week improves } \\
\text { cognitive and cardiorespiratory } \\
\text { health in mental spectrum } \\
\text { disorders and decreases } \\
\text { depressive symptoms. }\end{array}$ \\
\hline
\end{tabular}




\begin{tabular}{l|l|l|l|l|l}
\hline Vancampfort \& & 2018 & Book & BD & & $\begin{array}{l}\text { Bipolar disorder and } \\
\text { physical activity }\end{array}$ \\
Chapter-3 & & $\begin{array}{l}\text { In cases where physical activity } \\
\text { studies are included in routine } \\
\text { management in the treatment of } \\
\text { BD patients, it is important to } \\
\text { increase the quality of life of this } \\
\text { population in relation to mental } \\
\text { and physical health in reducing } \\
\text { the different morbidity and } \\
\text { mortality rates. }\end{array}$ \\
\hline
\end{tabular}

Van Citters and colleagues (50) with in the period of 9 months, in the study which consists of participants who have schizophrenia, bipolar disorder and major depressive disorder, an individual health consultant was assigned to determine the objects which are related to other healthy living modules as well as healthy and regular nutrition program. The program was controlled with moderate walking exercise. They found a significant increase in the mental health of the participants and a significant decrease in the waist circumference.

Sylvia and colleagues (44) has developed Nutrition, Exercise and Healthy Life Therapy in addition to psychotherapy to help individuals who have bipolar disorder while they acquire healthier lifestyle habits. This therapy consists of three modules that aim to change food intake with more nutritious and portion control, increasing weekly exercise as well as improving other health areas (i.e. sleeping, smoking / substance use). In the pilot study of treatment, five participants completed a 20week individual cognitive-behavioral therapy-based treatment and there was a moderate decrease in depression levels. Participants reported that they were satisfied with the treatment by participating in most of these integrated therapy sessions. In addition to this, it has been determined that they increased the intake of vegetables and decreased the daily sweetness in their nutritional habits. Body weight, cholesterol (high density lipoprotein cholesterol and low density lipoprotein) triglycerides and plasma glucose levels of participants decreased until to 20th week. Participants did not only triple the amount of exercise, but also improved their depressive symptoms. This is one of the first studies which establish the practicality and tolerability of an intensive lifestyle study of bipolar disorder and its effectiveness offers promising data. These studies show some promises that participants who have serious mental illnesses will be successful in the general population and they can be successful in health programs. In order to examine the effectiveness of these programs better, it is crucial to carry out further studies on this quality in controlled studies.

Wright and colleagues (53) conducted a semistructured study in which 25 people who have bipolar disorder were interviewed about their experiences in exercise and disease. Specifically, they stated that exercise may be beneficial in this population, but that excessive and severe exercise is adverse because it may increase manic symptoms and potentially increase their manic and hypo manic symptoms. While the aggravation of manic symptoms affects the mood directly or indirectly, they draw attention to the reduction of violent exercises that are presumed to be a psychological risk in the disease. Interestingly, patients stated that rhythmic exercise forms may provide a calming effect and may facilitate mood regulation thanks to the gradual structure of activities such as walking, running or swimming.

Correspondingly, Sylvia and colleagues (45) conducted a comparative study with quetiapine which is a second-generation antipsychotic against lithium a classical mood stabilizer in 482 patients with bipolar disorder. At the beginning of the study, individuals who have a manic or hypo manic condition were found that they are tending to exercise more frequently than individuals with depression. Data from the study support that there may be a complex relationship between bipolar disorder and exercise, however it is unclear whether moods can maintain exercise behavior or have a bidirectional relationship. The authors suggest that there is a special relationship between exercise frequency and mood and people who have bipolar disorder reported that they have less exercise in 
their depressive periods. While the relationship of increased energy and activity to mania and depression may be an example of the basic symptomatology of the disease, another explanation of this relationship is related to the behavioral activation system $(36 ; 53)$.

Wright and colleagues (53) stated that although some participants have an increase of manic symptoms, some have a calming effect on hypomania, Suto and colleagues (42) for patients who have bipolar disorder, it is necessary to establish a special health strategy for finding the right type of exercise. As well as this is a controversial discussion, it shows that there is a need for current studies which are examining the effects of exercise during mania and hypomania in this population. The researchers also argue that among the most useful factors in treating bipolar disorder are a specific theme for finding the right type of exercise that can be useful individually (exercise and rest intervals). Although they are qualitative, these studies emphasize that the components such as type, intensity, frequency and duration of exercise can be particularly important when examining the relationship between exercise program and bipolar disorder. Although it has been suggested that exercise may have a significant impact on individuals with bipolar disorder, empirical evidence is needed to support this claim. Daumit and colleagues (12), 18-month group exercise sessions and individual weight management sessions studies included patients who have bipolar disorder $(\mathrm{n}=64,22 \%)$, severe mental illness such as schizophrenia, and schizoaffective disorder, including individuals with major depression $(n=291)$. According to the results of the study, it was found that the experimental group lost more weight than the control group and $37.8 \%$ of the participants who are in the experimental group lost at least $5 \%$ of the initial weight compared with $22.7 \%$ of the participants who are in the control group. These findings suggest that overweight or obese individuals who have severe mental illness can apply lifestyle changes which is taught by a study although daily difficulties caused by their illness.

Vancampfort and colleagues (48) according to the results of their study, individuals who have bipolar disorder were insufficient in their participation in physical activities and they had low correlations related to self-efficacy, Comorbidities, education and social isolation. The individuals who Turk ل Sport Exe 2019; 21(I):阽-I09

(ㄱ 2019 Faculty of Sport Sciences, Selcuk University have bipolar disorder had a low participation in physical activities and difficulties in directing these individuals to activities cause an increase in BMI, but they are idle due to low income levels and lack of health insurance.

Janney and colleagues (24), in their study with 60 outpatients who have bipolar disorder, they found that $78 \%$ of the participants were classified as sedentary (13.5 hours per day), and no participants could complete the 150-minute moderate / severe exercise recommended by the EPA. These findings are consistent with a number of other studies which have a high rate of physical inactivity in people who have bipolar disorder (25). In general, levels of physical activity in bipolar disorder appear to be lower than in the general population, but the data are uncertain (24). For instance, a national study in Canada found no significant difference in physical activity between individuals who have and have not bipolar disorder (7). After all, individuals who have bipolar disorder are limited to reporting on their own, and only to assess their physical activity during leisure time. Moreover, methodological changes which related to the method of evaluation of physical activity make comparison difficult among studies. When taken into consideration the many factors that negatively affect physical activity, such as excessive weight, smoking habits, and side effects of drugs used in bipolar disorder, it is not surprising that data show a higher probability of having sedentary lifestyles $(16,48)$. In the study which is conducted by Melo and colleagues (30), it was stated that the depressive symptoms of bipolar patients attending physical activities decreased, and their quality of life and functionality increased. In addition to this, the sedentary lifestyle ranged from $40 \%$ to $64.9 \%$.

Merikangas and colleagues (31), they deliberated the control group which included totally 242 men and women with 25 Bipolar I disorder, 29 with bipolar II disorder, 91 with depressive disorder and 97 with no history of mood disorder in their studies. For 2 weeks, the researchers used electronic scales (actigraphy device) to evaluate their daily energy levels, emotions, and physical activity levels. Participants scored their moods and energy levels 4 times a day (morning, lunch, evening, and bedtime) using scales consisting of seven items. These are "very happy, "very sad" and "very tired". It was found that a higher activity level, increased mood and increased energy at the next times (such as lunch time) were associated in the morning. 
Similarly, an increased energy level at a certain time was associated with increased activity at the next times. The results of the study show that the increase in physical activity decreases mental disorders and improves general health in adults (especially those who have bipolar I disorder). The biological systems which involved in regulating motor activity are complexly linked to other homeostatic systems such as sleep, feeding behavior, energy, and mood. Mobile monitoring technology allows real-time evaluation of these multiple systems.

Stubbs and colleagues (41) reported that physical activity plays a significant role in reducing the burden of mental health symptoms in patients who have bipolar and schizophrenia. It also provides evidence that patients who have mental disorders may exhibit cardiovascular disease symptoms between the ages of 30 and 40 , and the exercise plays a crucial role in reducing these symptoms and improving physical health. According to experts who suggest doing exercise in addition to standard medication and psychotherapy to better treat mental diseases, exercising two to three times a week with a structured physical activity program can reduce the symptoms of depression and schizophrenia. In addition to the treatment of mental disorders, the European Psychiatric Association (EPA) has advocated exercise and published a new guideline to encourage it. Scientists gathered together on the EPA guidelines published in the European Psychiatry Association and they suggested that a structural exercise program should be added to standard drug therapy and psychotherapy. Researchers reported that exercise effectively reduced symptoms of mental disorder, improved cognitive functions, and enhanced cardiovascular health among patients who have schizophrenia. Results of the study shows that aerobic exercise which performed at moderate intensity for at least 150 minutes per week improves cognitive and cardiorespiratory health in schizophrenia spectrum disorders and decreases depression and schizophrenia symptoms. Also the results support combining aerobic and resistance exercise in the treatment of schizophrenia spectrum disorder and patients who have major depression. The EPA guideline was also supported by the International Organization of Mental Health Physical Therapists (IOPTMH) (41). Vancampfort and Goldstein (49) examined the physical health conditions of people who have BD. The authors hope that the rapidly increasing evidence for the importance of exercise in the treatment of $\mathrm{BD}$ patients will provide a sustainable health policy change over time, where physical activity studies are included in routine management. Such kind of change is essential for improving the quality of life of this population related to mental and physical health in reducing different morbidity and mortality rates.

\section{CONCLUSION AND SUGGESTIONS}

Most of the drugs which used to treat bipolar disorder cause an increase in appetite and weight gain and they lead decrease self-confidence and reduced quality of life. Most studies focus on strategies to reduce weight gain instead of antidisease strategies. Preventive and early intervention strategies are more important than weight loss strategies in patient management. The effectiveness of pharmacological therapies in chronic psychiatric disorders such as bipolar disorder is important, but the side effects of the drugs used should be considered. Experts recommend different strategies in addition to medication. Non-pharmacological strategies include cognitive and behavioral studies, nutritional counseling and exercise programs. Studies which are evaluating these strategies have a significant heterogeneity in terms of duration of study, duration of follow-up and intensity of studies. The cognitive and behavioral strategies include eating behaviors and nutritional habits, physical exercise programs, problem solving training, goal setting and social support. Nutrition counseling involves a daily reduction of 500-1,000 kcal / day and a reduction in calories which are taken from fats to $30 \%$. Exercise programs consist of 150 minutes of moderate intensity $(55-69 \%$ of maximum heart rate) exercise per week. These studies are generally named as "behavioral lifestyle programs" (26).

Some evidence suggests that there is a strong relationship between exercise and mania. Generally, exercise which applies in bipolar patients has been associated with improved health practices, including functionality and quality of life by reducing depressive symptoms (30). Almost all antipsychotics cause weight gain, increase the risk of metabolic complications and physical health and reduce adaptation with medication and daily life. Various strategies have been tried to reduce antipsychoticinduced weight gain (AIWG), and clinicians choose antipsychotics according to the diagnosis, efficacy 
and side-effect profile of the patient. Haloperidol, lurasidone, ziprasidone, aripiprazole and amilsulpride have the less risk of weight gain compared to other antipsychotics. However, the risk of weight gain due to antipsychotics is not the only factor that regulates antipsychotic choices. Clozapine, which is the drug with the highest risk of gaining weight, is the only antipsychotic that has received a license in psychiatric treatment. Similarly, olanzapine, which is rich the aspect of efficiency, has a higher risk of gaining more weight than most other antipsychotics.

Although the risk of weight gain is highest in the first year of treatment, monitoring carefully and early intervention are the first steps in AIWG treatment. Non-pharmacological interventions are important in the treatment of AIWG and it is seen that diet counseling, exercise studies, cognitive and behavioral strategies are equally as effective as individual and group therapies.

As in other treatment areas, decisions about drug selection and weight management should be taken by patients and doctors. Main approaches for weight management with antipsychotics:

- Making sure that the risk of weight gain and other side effects are considered when choosing antipsychotics,

- Performing regular Body Mass Index (BMI) measurements during the antipsychotic treatment, especially in the first few months of treatment, where the risk of weight gain is highest,

- Use of lifestyle approaches (increased physical activity and exercise, changes nutritional habits) to manage weight gain; for instance eating well- balanced and regularly, feeding smaller portions, restricting foods and beverages which are rich in sugar and fat and making exercise a habit can prevent weight gain in patients.

There is evidence that exercise may be an appropriate and effective strategy for dealing with the depressive stage of bipolar disorder, but more researches are necessary to determine the recommended intensity, duration and frequency of exercise programs. We believe that in bipolar disorder, more research is needed to get better results in this area because of excessive fluctuations in mood symptoms and high Comorbidity rate.

\section{REFERENCES}

1. Ak, M. Sezlev, D. Sutcigil, L. Akarsu, S. Ozgen, F. Yanik, T. The investigation of leptin and hypothalamic neuropeptides role in first attack psychotic male patients: olanzapine monotherapy 2013. Psychoneuroendocrinology. 38(3):341347. Doi:10.1016/j.psyneuen. 2012.06.012.

2. Allison, D.B., Mentore, J.L., Heo, M., Chandler, L. P., Cappelleri, J. C., Infante, M. C. \& Weiden, P. J. Antipsychotic-induced weight gain: a comprehensive research synthesis. Am J Psychiatry. 1999,156(11):1686-1696. Doi:10.1176/ajp.156.11.1686

3. Alsuwaidan, M.T., Kucyi, A., Law, C.W.Y. \& Mcintyre, R.S. Exercise and bipolar disorder: a review of neurobiological mediators. Neuromolecular Med. 2009 . 11, 328-336. Doi:10.1007/s12017-009-8079-9.

4. Bak, M., Fransen, A., Janssen, J., van Os, J., Drukker, M. Almost all antipsychotics result in weight gain: a metaanalysis. PLoS One. 2014, 9(4):e94112. Doi: 10.1371/journal.pone.0094112

5. Bressert, S. Introduction to Bipolar Disorder. Psych Central. (Retrieved on February 27, 2019), from https://psychcentral.com/disorders/bipolar/introduction-tobipolar-disorder/

6. Butler, M., Urosevic, S., Desai, P., Sponheim, S.R., Popp, J., Nelson, V. A., Thao, V., Sunderlin, B. Treatment for Bipolar Disorder in Adults: A Systematic Review. 2018, https://www.ncbi.nlm.nih.gov/books/NBK532183/pdf/Books helf_NBK532183.pdf

7. Cairney, J., Veldhuizen, S., Faulkner, G., Schaffer, A. \& Rodriguez, M.C. Bipolar disorder and leisure-time physical activity: results from a national survey of Canadians. Ment. Health Phys. Act. 2, 6570. Doi:10.1016/j.mhpa.2009.09.003

8. Carek, P. J., Laibstain, S. E., Carek S. M. Exercise for the treatment of depression and anxiety. Int. J. Psychiatry Med. 2011.41, 15-28. Doi:10.2190/PM.41.1.c

9. Cooper, S.J., Reynolds, G.P., Barnes, T., England, E., Haddad, P.M., Heald, A., Holt, R., Lingford-Hughes, A., Osborn, D., McGowan, O., Patel, M..X., Paton, C., Reid, P., Shiers, D., Smith, J. BAP guidelines on the management of weight gain, metabolic disturbances and cardiovascular risk associated with psychosis and antipsychotic drug treatment. J Psychopharmacol. 2016, 30(8):717-748. Doi: 10.1177/ 0269881116645254.

10. Creta, E., Fabbri, C., Serretti, A. Genetics of secondgeneration antipsychotic and mood stabilizer-induced weight gain in bipolar disorder: common and specific effects of key regulators of fat-mass homoeostasis genes. Pharmacogenet Genomics. 2015 Jul;25(7): 354-62. Doi: 10.1097/FPC.0000000000000144.

11. Crump, C., Sundquist, K., Winkleby, M.A., Sundquist, J. Comorbidities and mortality in bipolar disorder: a Swedish national cohort study. JAMA Psychiatry 2013,70, 931-939. Doi:10.1001/jamapsychiatry.2013.1394

12. Daumit, G. L., Dickerson, F. B., Wang, N. Y., Dalcin, A., Jerome, G. J., Anderson, C. A. M, Young, D. R., Frick, K. D., Yu, A., Gennusa, J. V., Oefinger, M., Crum, R. M., 
Charleston, J., Casagrande, S. S., Eliseo Guallar, E., Goldberg, R. W., Campbell, L. M., Lawrence J. Appel, L. J. A behavioral weight-loss intervention in persons with serious mental illness. N. Engl. J. Med. 2013,368, 1594-1602. Doi:10.1056/NEJMoa1214530

13. De Hert, M., Detraux, J., Van Winkel, R., Yu, W., Correll, C.U. Metabolic and cardiovascular adverse effects associated with antipsychotic drugs. Nat Rev Endocrinol. 2011,8(2):114-126. Doi: 10.1038/nrendo.2011.156.

14. De Hert, M., Yu, W., Detraux, J., Sweers, K., Van Winkel, R., Correll, C.U. Body weight and metabolic adverse effects of asenapine, iloperidone, lurasidone and paliperidone in the treatment of schizophrenia and bipolar disorder: a systematic review and exploratory meta-analysis. CNS Drugs. 2012, 26(9):733-759. Doi: 10.2165/11634500000000000-00000.

15. Detke, H.C., DelBello, M.P., Landry, J., Hoffmann, V.P., Heinloth, A., Dittman, R.W. A 52-Week Study of Olanzapine with a Randomized Behavioral Weight Counseling Intervention in Adolescents with Schizophrenia or Bipolar I Disorder. J Child Adolesc Psychopharmacol. 2016 Dec;26(10):922-934. Epub 2016 Sep 27. Doi:10.1089/cap. 2016.0010

16. Dodd, S., Brnabic, A. J., Berk, L., Fitzgerald, P. B., De Castella, A. R., Filia, S., Filia, K., Kelin, K., Smith, M., Montgomery, W., Kulkarni, J., Berk, M. A prospective study of the impact of smoking on outcomes in bipolar and schizoaffective disorder. Compr. Psychiatry 2010, 51, 504509. Doi:10.1016/ j.comppsych. 2009.12.001

17. Dome, P., Gonda, X., Rihmer, Z. Effects of smoking on health outcomes in bipolar disorder with a special focus on suicidal behavior. Neuropsychiatry 2, 2012, 429-441 Doi: 10.2217/npy.12.51

18. Fang, F., Wang, Z., Wu, R., Calabrese, J.R., Gao, K. Is there a 'weight neutral' second-generation antipsychotic for bipolar disorder?. Expert Rev Neurother. 2017 Apr; 17(4): 407-418. Doi: 10.1080/14737175.2016.1276284.

19. Fleischhacker, W.W., Heikkinen, M.E., Olie, J. P., Landsberg, W., Dewaele, P., McQuade, R. D., Loze, J. Y., Hennicken, D., Kerselaers, W. Effects of adjunc-tive treatment with aripiprazole on body weight and clinical efficacy in schizophrenia patients treated with clozapine: a randomized, double-blind, placebo-controlled trial. Int J Neuro-psychopharmacol. 2010,13(8): 1115-1125. Doi: 10.1017/S1461145710000490.

20. Goldberg, J. Antipsychotic Medication for Bipolar Disorder; Side Effects of Antipsychotic Drugs. WebMD Medical Reference. 2017, https://www.webmd.com/bipolar-disorder/ guide/ antipsychotic-medication\#1-2.

21. Gonçalves, P., Araujo, J. R., Martel, F. Antipsychoticsinduced metabolic alterations: focus on adipose tissue and molecular mechanisms. Eur Neuropsychopharmacol. 2015,25(1): 1-16. Doi: 10.1016/j.euroneuro.2014.11.008.

22. Grohol, J. Atypical Antipsychotics for Bipolar Disorder. Psych Central. 2018, https://psychcentral.com/lib/atypical-antipsychotics-forbipolar-disorder/.
23. Henderson, D. C., Vincenzi, B., Andrea, N. V., Ulloa, M., Copeland, P. M. Pathophysiological mechanisms of increased cardiometabolic risk in people with schizophrenia and other severe mental illnesses. Lancet Psychiatry. 2015,2(5):452-464. Doi: 10.1016/S2215-0366(15)00115-7.

24. Janney, C. A., Fagiolini, A., Swartz, H. A., Jakicic, J. M., Holleman, R. G., Richardson, C. R. Are adults with bipolar disorder active? Objectively measured physical activity and sedentary behavior using accelerometry. J. Affect. Disord. 2014, 152-154, 498-504. Doi: 10.1016/j.jad.2013.09.009

25. Kilbourne, A. M., Morden, N. E., Austin, K., Ilgen, M., Mccarthy, J. F., Dalack, G., Blow, F. C. Excess heart-diseaserelated mortality in a national study of patients with mental disorders: identifying modifiable risk factors. Gen. Hosp. Psychiatry 2009, 31, 555-563. Doi:10.1016/j.genhosppsych.2009.07.008

26. Lasikiewicz, N., Myrissa, K., Hoyland, A., Lawton, C.L. Psychological benefits of weight loss following behavioural and/or dietary weight loss interventions. A systematic research review. Appetite. 2014, 72: 123-137. Doi: 10.1016/j.appet.2013.09.017

27. Leucht, S., Cipriani, A., Spineli, L., Mavridis, D., Orey, D., Richter, F., Samara, M., Barbui, C., Engel, R. R., Geddes, J. R., Kissling, W., Stapf, M. P., Lässig, B., Salanti, G., Davis, J. M. Comparative efficacy and toler-ability of 15 antipsychotic drugs in schizophrenia: a multiple-treatments meta-analysis. Lancet. 2013， 382(9896):951-962. Doi: 10.1016/S01406736(13)60733-3.

28. Lu, M. L., Wang, T. N., Lin, T. Y., Shao, W. C., Chang, S. H., Chou, J. Y., Ho, Y. F., Liao, Y. T., Chen, V.C. Differential effects of olanzapine and clozapine on plasma levels of adipocytokines and total ghrelin. Prog Neuropsychopharmacol Biol Psychiatry. 2015, 58:47-50. Doi: 10.1016/j.pnpbp.2014.12.001

29. Maletic, V. Updates to the diagnosis and management of bipolar depression: Have we been going about this all wrong?. Presented at Elevate by Psych Congress 2017; March 3, 2017; San Francisco, CA. https://www.psychcongress.com/article/bipolar-disorderdeadly-disease-dangerous-comorbidities

30. Melo, M., Daher, E., Albuquerque, S. \& De Bruin, V. Exercise in bipolar patients: A systematic review. Journal of Affective Disorders. 2016, Doi:10.1016/j.jad.2016.03.004

31. Merikangas, K. R., Swendsen, J., Hickie I. B., Cui, L., Shou, H., Merikangas, A. K., Zhang, J., Lamers, F., Crainiceanu, C., Volkow, N. D., Zipunnikov, V. Real-time Mobile Monitoring of the Dynamic Associations Among Motor Activity, Energy, Mood, and Sleep in Adults With Bipolar Disorder. JAMA Psychiatry. 2018: 76(2):190-198. Doi:10.1001/jamapsychiatry.2018.3546.

32. Meyer, J. M., Ng-Mak, D. S., Chuang, C. C., Rajagopalan, K., Loebel, A. Weight changes before and after lurasidone treatment: a real-world analysis using electronic health records. Ann Gen Psychiatry. 2017 Oct 17;16:36. Doi: 10.1186/s 12991-017-0159-x.

33. Moylan, S., Eyre, H. A., Maes, M., Baune, B. T., Jacka, F. N., Berk, M. Exercising the worry away: how inflammation, oxidative and nitrogen stress mediates the beneficial effect of 
physical activity on anxiety disorder symptoms and behaviours. Neurosci. Biobehav. 2013, Rev. 37, 573-584. Doi:10.1016/j.neubiorev.2013.02.003

34. Olfson, M., Gerhard, T., Huang, C., Crystal, S., Stroup, T.S. Premature mortality among adults with schizophrenia in the United States. JAMA Psychiatry. 72(12):1172-1181. Doi: 10.1001/jamapsychiatry.2015.1737.

35. Ostacher, M., Ng-Mak, D., Patel, P., Ntais, D., Schlueter, M., Loebel, A. Lurasidone compared to other atypical antipsychotic monotherapies for bipolar depression: A systematic review and network meta-analysis. World J Biol Psychiatry. 2018, 19(8):586-601. Doi: 10.1080/15622975.2017.1285050.

36. Proudfoot, J., Whitton, A., Parker, G., Doran, J., Manicavasagar, V., Delmas, K. Triggers of mania and depression in young adults with bipolar disorder. J. Affect. Disord. 2012, 143, 196-202. Doi:10.1016/j.jad.2012.05.052

37. Rado, J. \& Cavanaugh, S. A Naturalistic Randomized Placebo-Controlled Trial of Extended-Release Metformin to Prevent Weight Gain Associated With Olanzapine in a US Community-Dwelling Population. J Clin Psychopharmacol. $2016 \quad$ Apr;36(2):163-8. Doi: 10.1097/JCP.0000000000000469.

38. Roshanaei-Moghaddam, B. \& Katon, W. Premature mortality from general medical illnesses among persons with bipolar disorder: a review. Psychiatr. Serv. 2009, 60, 147-156. Doi:10.1176/ps.2009.60.2.147

39. Rubio-Terrés, C., Rubio-Rodríguez, D., Baca-Baldomero, E. Cost analysis of the adverse reactions of bipolar disorder treatment with aripiprazole and olanzapine in Spain. Actas Esp Psiquiatr. 2014 Sep-Oct;42(5):242-9. Epub 2014 Sep 1.

40. Rummel-Kluge, C., Komossa, K., Schwarz, S., Hunger, H., Schmid, F., Lobos, C. A., Kissling, W., Davis, J. M., Leucht, S.. Head-to-head com-parisons of metabolic side effects of second generation antipsychotics in the treatment of schizophrenia: a systematic review and meta-analysis. Schizophr Res. 2010.123(2-3):225-233. Doi: 10.1016/j.schres.2010.07.012

41. Stubbs, B., Vancampfort, D., Hallgren, M., Hallgren, M., Firth, J., Veronese, N., Solmi, M., Brand, S., Cordes, J., Malchow, B., Gerber, M., Schmitt, A., Correll, C. U., De Hert, M., Gaughran, F., Schneider, F., Kinnafick, F., Falkai, P., Möller, H. J., Kahl, K. G. EPA guidance on physical activity as a treatment for severe mental illness: a meta-review of the evidence and Position Statement from the European Psychiatric Association (EPA), supported by the International Organization of Physical Therapists in Mental Health (IOPTMH) European Psychiatry. pp. 124-144. http://dx.doi.org/10.1016/j.eurpsy.2018.07.004

42. Suto, M., Murray, G., Hale, S., Amari, E., Michalak, E. E. What works for people with bipolar disorder? Tips from the experts. J. Affect. Disord. 2010， 124， 76-84. Doi:10.1016/j.jad.2009.11.004

43. Sylvia, L. G., Ametrano, R. M., Nierenberg, A. A. Exercise treatment for bipolar disorder: potential mechanisms of action mediated through increased neurogenesis and decreased allostatic load. Psychother. Psychosom. 2010, 79, 87-96. Doi:10.1159/000270916
44. Sylvia, L. G., Nierenberg, A. A., Stange, J. P., Peckham, A. D., Deckersbach, T. Development of an integrated psychosocial treatment to address the medical burden associated with bipolar disorder. J. Psychiatr. Pract 2011. 17, 224-232. Doi: 10. 1097/01.pra.0000398419.82362.32

45. Sylvia, L. G., Friedman, E. S., Kocsis, J. H., Bernstein, E. E., Brody, B. D., Kinrys, G., Kemp, D. E., Shelton, R. C., McElroy, S. L., Bobo, W. V., Kamali, M., McInnis, M. G., Tohen, M., Bowden, C. L., Ketter, T. A., Deckersbach, T., Calabrese, J. R., Thase, M. E., Reilly-Harrington, N. A., Singh, V., Rabideau, D. J., Nierenberg, A. A. Association of exercise with quality of life and mood symptoms in a comparative effectiveness study of bipolar disorder. J. Affect. Disord. 2013a. 151, 722-727. Doi:10.1016/j.jad.2013.07.031

46. Sylvia, L. G., Salcedo, S., Bernstein, E. E., Baek, J. H., Nierenberg, A. A., Deckersbach, T. Nutrition, Exercise, and Wellness Treatment in bipolar disorder: proof of concept for a consolidated intervention. Int. J. Bipolar Disord. 2013b.1, 24. Doi:10.1186/2194-7511-1-24

47. Talaeı, A., Farıdhosseını, F., Kazemı, H., Fayyazı Bordbar, M.R., Rezae1 Ardan1, A. Effect of Topiramate on Drug Associated Weight Gain of Patients with Schizophrenia and Bipolar I Disorders: A Dose Ranging Randomized Trial, Turk Psikiyatri Derg. 2016 Summer; 27(2):0. https://www.ncbi.nlm.nih.gov/pubmed/27370059

48. Vancampfort, D., Correll, C., Probst, M., Sienaert, P., Wyckaert, S., De Herdt, A., Knapen, J., De Wachter, D. \& De Hert, M. A review of physical activity correlates in patients with bipolar disorder. Journal of Affective Disorders. 2013. Doi: 10. 1016/ j.jad. 2012.07.020

49. Vancampfort, D. \& Goldstein, B.I. Bipolar Disorder and Physical Activity. Exercise-Based Interventions for Mental Illness. Physical Activity as Part of Clinical Treatment. 1 st Edition; Chapter 3. 2018, pp. 53-63.

50. Van Citters, A. D., Pratt, S. I., Jue, K., Williams, G., Miller, P. T., Xie, H., Bartels, S. J. A pilot evaluation of the in SHAPE individualized health promotion intervention for adults with mental illness. Community Ment. Health J. 2010, 46, 540-552. Doi:10.1007/s10597-009-9272-x

51. Vieta, E. \& Montes, J. M. A Review of Asenapine in the Treatment of Bipolar Disorder. Clin Drug Investig. 2018, 38(2):87-99. Doi: 10.1007/s40261-017-0592-2.

52. Wildes, J., Marcus, M., Fagiolini, A. Obesity in patients with bipolar disorder: A biopsychosocial-behavioral model. Journal of Clinical Psychiatry. 2006, 67(6):904-915. https://www.psychiatrist.com/jcp/article/Pages/2006/v67n06/ v67n0607.aspx

53. Wright, K., Armstrong, T., Taylor, A., Dean, S. "It's a double edged sword": a qualitative analysis of the experiences of exercise amongst people with Bipolar Disorder. J. Affect. Disord. 2012, 136, 634-642. Doi:10.1016/j.jad.2011.10.017

54. Zhang, J.P., Lencz, T., Zhang, R.X., Nitta, M., Maayan, L., John, M., Robinson, D. G., Fleischhacker, W. W., Kahn, R. S., Ophoff, R. A., Kane, J. M., Malhotra, A., K., Correll, C. U. Pharmacogenetic associations of antipsychotic drug-related weight gain: a systematic review and meta-analysis. Schizophr Bull. 2016, 42(6):1418-1437. Doi: 10.1093/schbul/sbw058. 